Technical Note

\title{
Simultaneous removal of arsenite and fluoride via an integrated electro-oxidation and electrocoagulation process
}

\author{
Xu Zhao, Baofeng Zhang, Huijuan Liu, Jiuhui Qu* \\ State Key Laboratory of Environmental Aquatic Chemistry, Research Center for Eco-Environmental Sciences, Chinese Academy of Sciences, Beijing 100085, PR China
}

\section{A R T I C L E I N F O}

\section{Article history}

Received 30 September 2010

Received in revised form 25 January 2011

Accepted 25 January 2011

\section{Keywords:}

Groundwater

Arsenite

Fluoride

Electrochemical treatment

\begin{abstract}
A B S T R A C T
An integrated electro-oxidation and electrocoagulation system was designed and used to remove As(III) and $\mathrm{F}^{-}$ions from water simultaneously. Dimensionally stable anodes (DSA), Fe electrodes, and Al electrodes were combined into an electrochemical system. Two pieces of DSA electrodes were assigned as the outside of the Fe and $\mathrm{Al}$ electrodes and were directly connected to the power supply as anode and cathode, respectively. The Fe and Al ions were generated by electro-induced process simultaneously. Subsequently, hydroxides of $\mathrm{Fe}$ and $\mathrm{Al}$ were formed. Arsenic ions are mainly removed by iron hydroxides and $\mathrm{F}^{-}$ions are mainly removed by the $\mathrm{Al}$ oxides. At the initial concentration of $1.0 \mathrm{mg} \mathrm{L}^{-1}$, most of $\mathrm{As}(\mathrm{III})$ was transferred into $\mathrm{As}(\mathrm{V})$ within $40 \mathrm{~min}$ at current density of $4 \mathrm{~mA} \mathrm{~cm}^{-2}$, whereas $\mathrm{F}^{-}$ions can be efficiently removed simultaneously. The effect of the ratio of $\mathrm{Fe}$ and $\mathrm{Al}$ plate electrodes and current density on the removal of $\mathrm{As}(\mathrm{III})$ and $\mathrm{F}^{-}$was investigated. With one piece of Fe plate electrode and three pieces of $\mathrm{Al}$ plate electrodes, it is observed that As(III) with concentration of $1 \mathrm{mg} \mathrm{L}^{-1}$ and $\mathrm{F}^{-}$with concentration of $4.5 \mathrm{mg} \mathrm{L}^{-1}$ can be removed and their final concentrations were below the values of $10 \mu \mathrm{g} \mathrm{L}^{-1}$ and $1.0 \mathrm{mg} \mathrm{L}^{-1}$, respectively within $40 \mathrm{~min}$. Removal efficiency of $\mathrm{As}(\mathrm{III})$ increases with the increase of solution $\mathrm{pH}$. However, in the $\mathrm{pH}$ range of $6-7$, removal efficiency of $\mathrm{F}^{-}$is the largest.
\end{abstract}

(c) 2011 Elsevier Ltd. All rights reserved.

\section{Introduction}

Groundwater contamination has been a major issue due to the presence of various pollutants such as fluoride, pesticides, and arsenic. Fluoride is essential to prevent dental caries but an excess intake is detrimental to human health. The suitable level of fluoride ions in drinking water specified by the World Health Organization is $1.5 \mathrm{mg} \mathrm{L}^{-1}$ (Tripathy et al., 2006). However, the concentration of fluoride ion in groundwater is higher than $1.5 \mathrm{mg} \mathrm{L}^{-1}$ in many areas throughout the world. Fluoride removal techniques mainly include chemical precipitation (He and Cao, 1996), membrane processes (Tahaikt et al., 2007), adsorption (Maliyekkal et al., 2006; Wu et al., 2007), and ion exchange (Meenakshi and Viswanathan, 2007). Adsorption is effective in defluoridation, but its operation is complex. Coagulation is simple in equipment and effective in defluoridation under proper conditions, but large amounts of contaminants such as $\mathrm{SO}_{4}^{2-}$ are introduced to the water, especially when the fluoride ion concentration is high. The membrane processes are known to be effective for defluoridation. However, a common problem is their poor selectivity. It is suitable for treatment water containing high content of fluoride.

Arsenic, a toxic trace element present in groundwater, is a major unavoidable threat for the life of human beings and useful

\footnotetext{
* Corresponding author. Tel.: +86 10 62849151; fax: +86 1062923558 .

E-mail address: jhqu@rcees.ac.cn (J. Qu).
}

microorganisms (Ghiew et al., 2009). Arsenic exists in groundwater predominantly as $\mathrm{As}(\mathrm{III})$ and $\mathrm{As}(\mathrm{V}) . \mathrm{As}(\mathrm{III})$ is the dominant form in anaerobic groundwater, and being more toxic than $\mathrm{As}(\mathrm{V})$. As(III) is more difficult to be removed from water than $\mathrm{As}(\mathrm{V})$ because of the lack of electrostatic attraction on the solid. Commonly used processes for arsenic removal include oxidation and sedimentation, coagulation and filtration, lime treatment, adsorption onto sorptive media, ion exchange and membrane filtration (Wang et al., 2003; Berg et al., 2006; Jang et al., 2006; Boddu et al., 2008). The major disadvantage of these techniques is that they are unable to removal As(III) efficiently. Thus, oxidation of arsenite is considered a prerequisite for the treatment method to be efficient.

Recently, electrocoagulation (EC) has a more prominent role in the drinking treatment because it provides some significant advantages such as quite compact and easy operation and automation, no chemical additives, high velocities and reduced amount of sludge (Holt et al., 2002). Generally, the Fe and Al plates are used as anode materials and stainless steel is used as cathode material (Holt et al., 2002; Mollah et al., 2004). EC has been employed to perform defluoridation (Mameri et al., 1998; Hu et al., 2003). In the EC cell using $\mathrm{Al}$ as anode, sacrificial dissolution of aluminum gives $\mathrm{Al}^{3+}$, which precipitates as $\mathrm{Al}(\mathrm{OH})_{3}$ in solutions of near neutral $\mathrm{pH}$ (Canizares et al., 2007). $\mathrm{Al}(\mathrm{OH})_{3}$ is further polymerized to $\mathrm{Al} n(\mathrm{OH})_{3} n$. The $\mathrm{Al}(\mathrm{OH})_{3}$ floc is believed to adsorb $\mathrm{F}^{-}$strongly (Emamjomeh and Sivakumar, 2009). When Fe plate was used as anode in the EC process, $\mathrm{As}(\mathrm{V})$ can be efficiently removed from 
contaminated water via the co-operation between Fe and As ions (Ratna Kumar et al., 2006). However, removal of As(III) was limited by EC method.

It is known that the anode oxidation is an efficient method in removing contaminants in aqueous solution. The contaminants can be destroyed by the direct electrochemical oxidation or indirect electrochemical oxidation induced by the electrogenerated active species (Chen, 2004). The electrocatalytic oxidation and detection of $\mathrm{As}(\mathrm{III})$ has been largely investigated at platinum wire (Lown and Johnson, 1980), and platinum disc (Williams and Johnson, 1992) electrodes and more recently at platinum nanoparticles modified carbon electrodes (Dai and Compton, 2006). The oxidation reaction is likely electrocatalyzed by the formation of platinum hydroxide on the electrode surface. Recently, three kinds of electrode materials of $\mathrm{Fe}, \mathrm{Al}$, and $\mathrm{Ti}$ were used to remove arsenic via electrocoagulation process (Ratna Kumar et al., 2006). It is observed that arsenic removal was the highest with iron electrodes. Dimensionally stable anode (DSA) electrode is widely used due to its high stability and high efficiency. DSA electrodes prepared by the deposition of a thin layer of metal oxides onto a base metal, usually titanium, are found to have various degrees of success in the application of environmental electrochemistry.

Herein, the combination of $\mathrm{Fe}, \mathrm{Al}$ and DSA electrodes in an electrochemical reactor was studied in order to remove $\mathrm{As}(\mathrm{III})$ and $\mathrm{F}^{-}$ ions simultaneously. The DSA electrode was connected to the direct current (DC) power and used as anode and cathode with frequent change of their polarity. The oxidation of As(III) can be achieved on the DSA anode. Meanwhile, the dissolution of Fe and $\mathrm{Al}$ anodes is produced by the electro-induced process.

\section{Experimental}

An EC unit was designed and built. It consisted of a $1.0 \mathrm{~L}$ activevolume, electrode chamber with $4.5 \times 7.5 \mathrm{~cm}$ long sheet-shaped $\mathrm{Fe}, \mathrm{Al}$ and DSA electrodes. The distance between the adjacent electrodes was $2 \mathrm{~mm}$. The effective surface area of each electrode was ca. $24 \mathrm{~cm}^{2}$. Two DSA electrodes were put outside and connected to the power and used as anode and cathode, respectively. The diagram of the experimental equipment is given in Fig. 1. With different amount ratio, $\mathrm{Fe}$ and $\mathrm{Al}$ plate electrodes were put in the middle of the DSA electrodes. The Fe and $\mathrm{Al}$ electrodes had no connection to the DC source. In such condition, induced polarization took place when voltage was applied to the DSA electrodes, leading to the dissolution of Fe and Al plate electrodes. The polarity of DSA electrodes is reversed each 15 min to avoid anode passivation of $\mathrm{Fe}$ and $\mathrm{Al}$ plate electrodes. A constant current was maintained using a potentiostat in galvanostatic mode. Magnetic stirring maintained a homogeneous solution in the batch reactor. All the experiments were performed in batch mode at a temperature of $25 \pm 2{ }^{\circ} \mathrm{C}$.

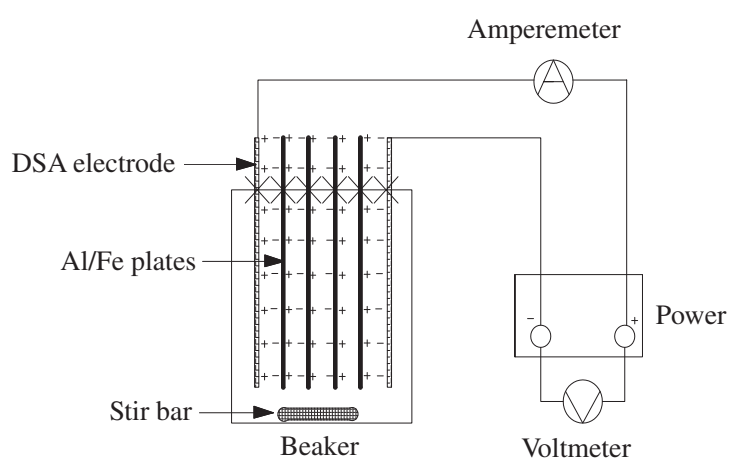

Fig. 1. The diagram of the experimental equipment.
A $1000 \mathrm{mg} \mathrm{L}^{-1}$ fluoride stock solution was prepared by dissolving $1.1030 \mathrm{~g} \mathrm{NaF}$ (analytical grade) in $500 \mathrm{~mL}$ distilled water. $\mathrm{F}^{-}$ ions bearing solutions were prepared by diluting the stock solution to different concentrations with deionized water. Concentration of $\mathrm{F}^{-}$ions was analyzed with a $\mathrm{F}^{-}$selective electrode connected to an ion meter (IM-40S, TOA, Japan). Stock As(III) solutions of $1000 \mathrm{mg} \mathrm{L}^{-1}$ were prepared according to the method described in our previous work (Zhang et al., 2007). And, analysis methods of $\mathrm{As}(\mathrm{III})$ and $\mathrm{As}(\mathrm{V})$ ions are also given in the above literature. Samples were taken for a given time from the effluent and the concentration of $\mathrm{As}(\mathrm{III})$ and $\mathrm{F}^{-}$ions was measured after filtration $(0.45 \mu \mathrm{m})$.

The filtrate samples were analyzed in order to determine the amount of residual arsenic and $\mathrm{F}^{-}$ions. In order to examine the conversion of $\mathrm{As}(\mathrm{III})$ to $\mathrm{As}(\mathrm{V})$, the sample including water and coagulant were treated by strong $\mathrm{HNO}_{3}$ and the coagulant was dissolved completely. Thus, the total As was measured.

\section{Results and discussion}

\subsection{Removal efficiency of arsenic and fluoride ions}

It can be seen from Fig. 2 that the $\mathrm{As}$ (III) and $\mathrm{F}^{-}$ions can be efficiently removed in the electrochemical process in the integrated reactor with three Fe plate and one Al plate electrodes under a current density of $4 \mathrm{~mA} \mathrm{~cm}^{-2}$. The $\mathrm{As}(\mathrm{III})$ ion with initial concentration of $1 \mathrm{mg} \mathrm{L}^{-1}$ was efficiently removed within $40 \mathrm{~min} . \mathrm{F}^{-}$ion was also efficiently removed. In contrast, removal of $\mathrm{As}(\mathrm{III})$ and $\mathrm{F}^{-}$ions by individual Fe electrode or $\mathrm{Al}$ electrode was also performed. In these experiments, the same amount of $\mathrm{Fe}$ or $\mathrm{Al}$ plate with same area and thickness was used. Within $40 \mathrm{~min}$, in the reaction system of four Fe electrodes, four Al electrodes, and three $\mathrm{Al}$ and one Fe electrodes, the removal efficiencies of $\mathrm{F}^{-}$ions are $8.1 \%, 89.0 \%$, and $81 \%$, respectively. Conversely, the removal efficiencies of $\mathrm{As}$ (III) are $100 \%, 7.5 \%$, and $98 \%$, respectively. It is concluded that As is removed by sorption on generated iron hydroxide, whereas $\mathrm{F}^{-}$is adsorbed on produced aluminum hydroxide, which further precipitate. Both processes are different.. Al metal dissolves as $\mathrm{Al}^{3+}$ which precipitates as " $\mathrm{Al}(\mathrm{OH})_{3}$ " with minimum solubility near $\mathrm{pH}$ 6. Fe metal dissolves as $\mathrm{Fe}^{2+}$, which must be oxidized to $\mathrm{Fe}^{3+}$, but is then highly insoluble throughout the $\mathrm{pH}$ range of typical waste or drinking water sources. These results indicate the advantage of the combined electrodes for the removal of $\mathrm{As}(\mathrm{III})$ and $\mathrm{F}^{-}$ ions.

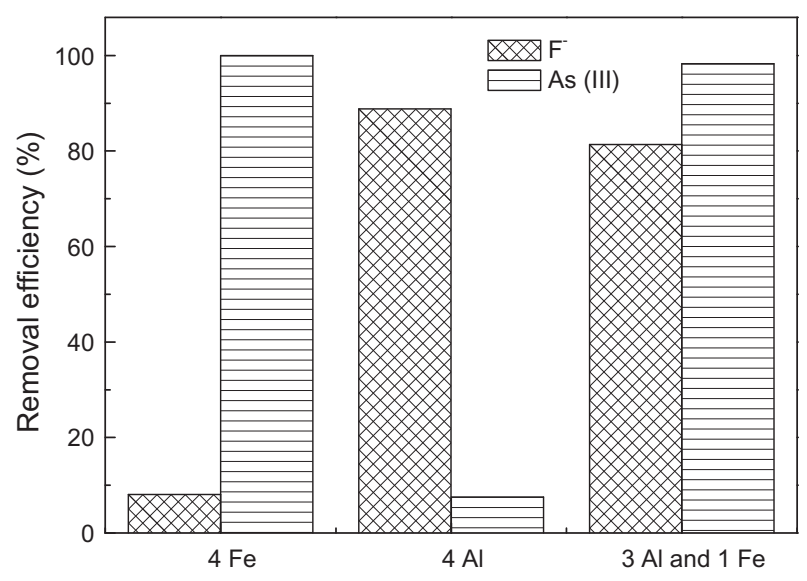

Fig. 2. Removal of $A s(I I I)$ and $F^{-}$ions in electrochemical process with different electrodes (initial concentration of $\mathrm{As}(\mathrm{III})$ and $\mathrm{F}^{-}$ions: 1.0 and $4.5 \mathrm{mg} \mathrm{L}^{-1}$ respectively; current density of $4 \mathrm{~mA} \mathrm{~cm}^{-2} ; 40 \mathrm{~min}$ ). 
3.2. Effect of ratio of Fe to Al plate electrode on the removal of arsenic and fluoride ions

Following, the effect of ratio of Fe to Al plate electrodes on the removal of $\mathrm{As}(\mathrm{III})$ and $\mathrm{F}^{-}$ions was investigated. As shown in Fig. 3, with the ratio of Fe plate to Al plate electrodes decreases, the removal efficiency of $\mathrm{F}^{-}$ions increases. The effect of ratio of Al plate to Fe plate electrodes on the As(III) removal is not obvious. It is suggested that the generated iron hydroxides were enough for the removal As(III) with one iron plate in the electrochemical process. In the case of the ratio of $\mathrm{Fe}$ to $\mathrm{Al}$ of $1: 3$, the $\mathrm{As}(\mathrm{III})$ and $\mathrm{F}^{-}$ions can be simultaneously removed within $40 \mathrm{~min}$. Thus, the ratio of $\mathrm{Fe}$ to $\mathrm{Al}$ was selected as 1:3 in the subsequent experiment.

\subsection{Effect of current density on the removal of arsenic and fluoride ions}

The effect of current density on the removal of $\mathrm{As}(\mathrm{III})$ and $\mathrm{F}^{-}$ions were investigated. The initial concentration of As(III) and $\mathrm{F}^{-}$ions was $1 \mathrm{mg} \mathrm{L}^{-1}$ and $4.5 \mathrm{mg} \mathrm{L}^{-1}$, respectively. It can be seen from Fig. 4 that removal rate of $\mathrm{As}$ (III) and $\mathrm{F}^{-}$ions increase with the increase of current density in the electrochemical process. The effect on $\mathrm{F}^{-}$ions removal is larger than that on $\mathrm{As}(\mathrm{III})$ removal. It is suggested that the amount of produced iron hydroxides was enough for As(III) removal with initial concentration of $1 \mathrm{mg} \mathrm{L}^{-1}$. The removal efficiency of $\mathrm{F}^{-}$ions increased with the increase of
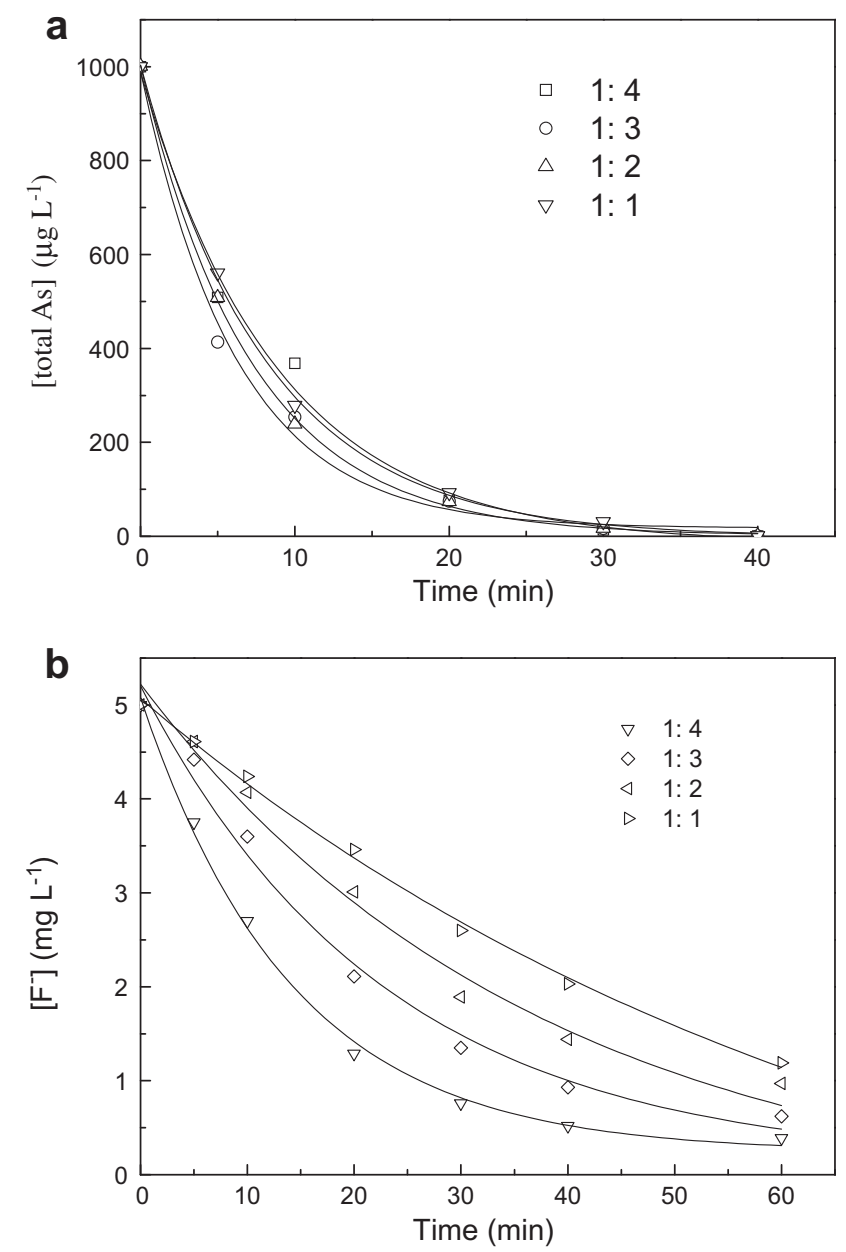

Fig. 3. Effect of the ratio of Fe to $\mathrm{Al}$ electrodes on the removal of $\mathrm{As}(\mathrm{III})$ (a) and $\mathrm{F}^{-}$ ions (b) in electrochemical process (initial concentration of $\mathrm{As}(\mathrm{III})$ and $\mathrm{F}^{-}$ions: 1.0 and $4.5 \mathrm{mg} \mathrm{L}^{-1}$ respectively; current density of $4 \mathrm{~mA} \mathrm{~cm}^{-2} ; 40 \mathrm{~min}$ ).

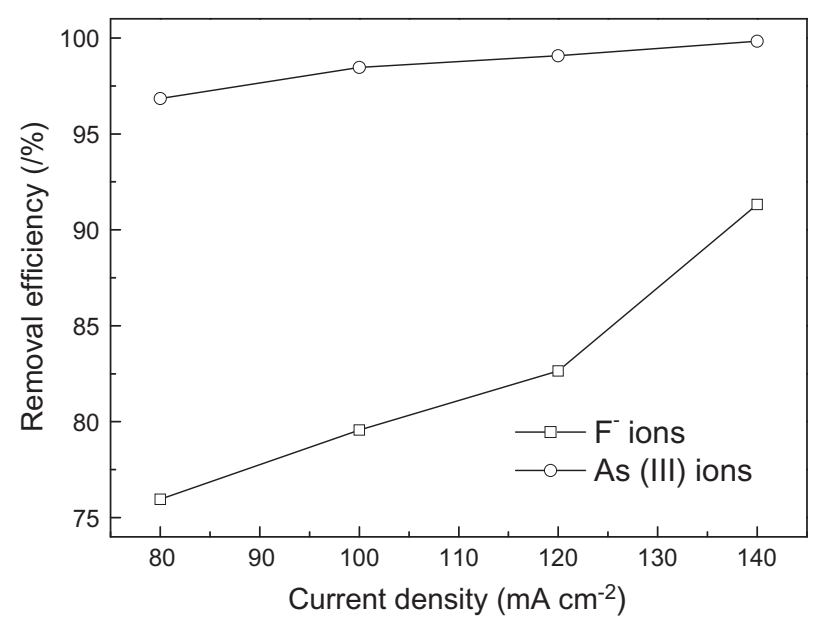

Fig. 4. Effect of current density on the removal of $\mathrm{As}(\mathrm{III})$ and $\mathrm{F}^{-}$ions in electrochemical process (initial concentration of $\mathrm{As}(\mathrm{III})$ and $\mathrm{F}^{-}$ions: 1.0 and $4.5 \mathrm{mg} \mathrm{L}^{-1}$ respectively; $40 \mathrm{~min}$ ).

current density, which can be induced by the increased amount of $\mathrm{Al}$ coagulants and $\mathrm{Al}$ hydroxides.

\subsection{Effect of $\mathrm{pH}$ on the removal of arsenic and fluoride ions}

It is observed from Fig. 5 that there is nearly no significant effect of $\mathrm{pH}$ on arsenic removal. In the examined $\mathrm{pH}$ range, all the removal efficiency was over 95\%, which is consistent with the results reported by Ratna Kumar et al. (2006). It is also noticed that the removal efficiency of $\mathrm{F}^{-}$ions increases with increasing $\mathrm{pH}$. The hydrolysis of $\mathrm{Fe}^{3+}$ will speed up and more Fe coagulant will be produced at high $\mathrm{pH}$, which will be responsible for the higher efficiency of As(III) removal.

A different variation trend was observed for the $\mathrm{F}^{-}$ions removal with the variation of solution $\mathrm{pH}$. When the initial $\mathrm{pH}$ value increased from 5 to 6 , the $\mathrm{F}^{-}$ions removal rate increased. By increasing the initial $\mathrm{pH}$ from 6 to 7 , the $\mathrm{F}^{-}$ion removal rate decreased slightly. Furthermore, the removal rate largely decreased when the $\mathrm{pH}$ is larger than $7 . \mathrm{F}^{-}$ion removal can be taken as the ion exchange of $\mathrm{F}^{-}$with $\mathrm{OH}^{-}$in $\mathrm{Al}(\mathrm{OH})_{3}$. When $\mathrm{OH}^{-}$concentration decreases, the ion exchange equilibrium shifts.

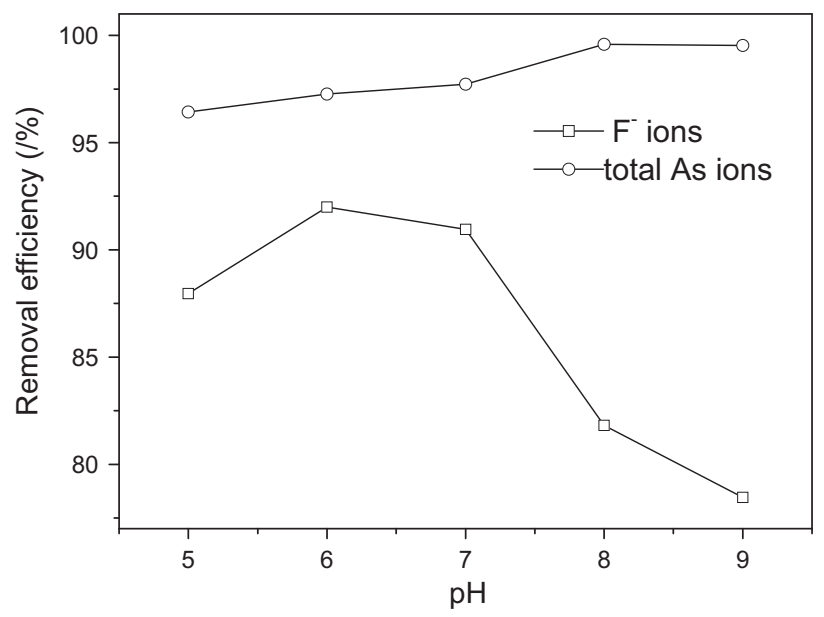

Fig. 5. Effect of solution $\mathrm{pH}$ on the removal of $\mathrm{As}(\mathrm{III})$ and $\mathrm{F}^{-}$ions in electrochemical process (initial concentration of $\mathrm{As}(\mathrm{III})$ and $\mathrm{F}^{-}$ions: 1.0 and $4.5 \mathrm{mg} \mathrm{L}^{-1}$ respectively; current density of $4 \mathrm{~mA} \mathrm{~cm}^{-2} ; 40 \mathrm{~min}$ ). 
Additionally, the solubility of total $\mathrm{Al}$ increases as $\mathrm{pH}$ increases. This explains why low $\mathrm{pH}$ value is beneficial to $\mathrm{F}^{-}$removal (Zhu et al., 2007).

\section{Conclusions}

It has been demonstrated that $\mathrm{As}(\mathrm{III})$ and $\mathrm{F}^{-}$ions can be efficiently removed in the integrated electro-oxidation and EC reactor simultaneously with the ratio of $\mathrm{Fe}$ to Al plate electrode of 3:1 and optional current density of $4 \mathrm{~mA} \mathrm{~cm}^{-2}$. Most As(III) was oxidized to $\mathrm{As}(\mathrm{V})$ in the reaction process. The oxidation is induced by electrooxidation at the DSA electrode. The optimal $\mathrm{pH}$ range is 5-7 for the efficient removal of $\mathrm{As}(\mathrm{III})$ and $\mathrm{F}^{-}$ions. The experimental results indicated that the electro-oxidation and EC process using combined $\mathrm{Fe}, \mathrm{Al}$ and DSA electrodes can be used to efficiently remove As(III) and $\mathrm{F}^{-}$ions simultaneously.

\section{Acknowledgment}

This work was supported by the National Natural Science Foundation of China (No. 50921064 and 20977103).

\section{References}

Berg, M., Luzi, S., Trang, P.T.K., Viet, P.H., Giger, W., Stuben, D., 2006. Arsenic removal from groundwater by household sand filters: comparative field study, model calculations, and health benefits. Environ. Sci. Technol. 40, 5567-5573.

Boddu, V.M., Abburi, K., Talbott, J.L., Smith, E.D., Haasch, R., 2008. Removal of arsenic (III) and arsenic (V) from aqueous medium using chitosan-coated biosorbent Water Res. 42, 633-642.

Canizares, P., Jimenez, C., Martinez, F., Saez, C., Rodrigo, M.A., 2007. Study of the electrocoagulation process using aluminum and iron electrodes. Ind. Eng. Chem. Res. 46, 6189-6195.

Chen, G.H., 2004. Electrochemical technologies in wastewater treatment. Sep. Purif. Technol. 38, 11-41.

Dai, X., Compton, R., 2006. Detection of As(III) via oxidation to As(V) using platinum nanoparticles modified glassy carbon electrodes: arsenic detection without interference from copper. Analyst 131, 516-521.

Emamjomeh, M.M., Sivakumar, M., 2009. Fluoride removal by a continuous flow electrocoagulation reactor. J. Environ. Manage. 90, 1204-1212.
Ghiew, H., Sampson, M.L., Huch, S., Ken, S., Bostick, B.C., 2009. Effect of groundwater iron and phosphate on the efficacy of arsenic removal by iron-amended biosand filters. Environ. Sci. Technol. 38, 2919-2927.

He, G.L., Cao, S.R., 1996. Assessment of fluoride removal from drinking water by calcium phosphate systems. Fluoride 29, 212-216.

Holt, P.K., Barton, G.W., Wark, M., Mitchell, C.A., 2002. A quantitative comparison between chemical dosing and electrocoagulation. Colloids Surf., A 211, 233248.

Hu, C.Y., Lo, S.L., Kuan, W.H., 2003. Effects of co-existing anions on fluoride removal in electrocoagulation (EC) process using aluminum electrodes. Water Res. 37, 4513-4523.

Jang, M., Min, S.H., Kim, T.H., Park, J.K., 2006. Removal of arsenite and arsenate using hydrous ferric oxide incorporated into naturally occurring porous diatomite. Environ. Sci. Technol. 40, 1636-1643.

Lown, J.A., Johnson, D.C., 1980. Anodic detection of arsenic (III) in a flow-through platinum electrode for flow-injection analysis. Anal. Chim. Acta 116, 41-51.

Maliyekkal, S.M., Sharma, A.K., Philip, L., 2006. Manganese-oxide-coated alumina: a promising sorbent for defluoridation of water. Water Res. 40, 3497-3506.

Mameri, N., Yeddou, A.R., Lounici, H., Belhocine, D., Grib, H., Bariou, B., 1998. Defluoridation of septentrional Sahara water of North Africa by electrocoagulation process using bipolar aluminium electrodes. Water Res. 32, 1604-1612.

Meenakshi, S., Viswanathan, N., 2007. Identification of selective ion-exchange resin for fluoride sorption. J. Colloid Interface Sci. 308, 438-450.

Mollah, M.Y.A., Morkovsky, P., Gomes, J.A.G., Kesmez, M., Parga, J., Cocke, D.L., 2004. Fundamentals, present and future perspectives of electrocoagulation. J. Hazard. Mater. 114, 199-210.

Ratna Kumar, P., Chaudhari, S., Khilar, K.C., Mahajan, S.P., 2006. Removal of arsenic from water by electrocoagulation. Chemosphere 55, 1245-1253.

Tahaikt, M., El Habbani, R., Ait Haddou, A., Achary, I., Amor, Z., Taky, M., Alami, A. Boughriba, A., Hafsi, M., Elmidaoui, A., 2007. Fluoride removal from groundwater by nanofiltration. Desalination 212, 46-53.

Tripathy, S.S., Bersillon, J.-L., Gopal, K., 2006. Removal of fluoride from drinking water by adsorption onto alum-impregnated activated alumina. Sep. Purif. Technol. 50, 310-317.

Wang, J.W., Bejan, D., Bunce, N.J., 2003. Removal of arsenic from synthetic acid mine drainage by electrochemical $\mathrm{pH}$ adjustment and coprecipitation with iron oxide. Environ. Sci. Technol. 37, 4500-4506.

Williams, D.G., Johnson, D.C., 1992. Pulsed voltammetric detection of arsenic (III) at platinum electrodes in acidic media. Anal. Chem. 64, 1785-1789.

Wu, X., Zhang, Y., Dou, X., Yang, M., 2007. Fluoride removal performance of a novel $\mathrm{Fe}-\mathrm{Al}-\mathrm{Ce}$ trimetal oxide adsorbent. Chemosphere 69, 1758-1764

Zhang, G.S., Qu, J.H., Liu, H.J., Liu, R.P., Li, G.T., 2007. Removal mechanism of As(III) by novel $\mathrm{Fe}-\mathrm{Mn}$ binary oxide adsorbent: oxidation and sorption. Environ. Sci. Technol. 41, 4613-4619.

Zhu, J., Zhao, H.Z., Ni, J.R., 2007. Fluoride distribution in electrocoagulation defluoridation process. Sep. Purif. Technol. 56, 184-191. 